\title{
THE RELATIONSHIP BETWEEN SATISFACTION, TRUST AND REPURCHASE INTENTION: EXAMINING THE MODERATING ROLE OF WORD OF MOUTH
}

\author{
HO TRONG NGHIA \\ University of Economics Ho Chi Minh City, Vietnam - nghiaht@ueh.edu.vn \\ BUI THI THANH \\ University of Economics Ho Chi Minh City, Vietnam - btthanh@ueh.edu.vn \\ DIEP QUOC BAO \\ University of Economics Ho Chi Minh City, Vietnam - baodq@ueh.edu.vn
}

(Received: September 12, 2017; Revised: October 22, 2017; Accepted: October 31, 2017)

\begin{abstract}
Underlying by Cognitive Dissonance Theory, this study aims to examine the moderating effect of word of mouth (WOM) on the relationship between consumers' satisfaction and trust. The research also emphasizes on figuring out the differences in moderating effects of WOM between online and conventional shopping context. In addition, the impact of trust on repurchase intention is also investigated. Applying Structural Equation Modeling, data collected from 296 online consumers and 169 conventional shoppers has been analyzed to figure out the associations among these concepts in both shopping context. The results indicate that word of mouth significantly plays moderating role in the relationship between satisfaction and trust. In addition, it is obviously evidenced that moderating effect of WOM varies due to different shopping context and the interactions of satisfaction, trust and repurchase intention are also different. The findings provide a better understanding regarding consumer behavior in different shopping environments. Consequently, practical implications for marketers and theoretical implications for scholars are discussed.
\end{abstract}

Keywords: Repurchase intention; Satisfaction; Trust; Word of mouth.

\section{Introduction}

Satisfaction and trust are key factors in tightening buyer - seller relationship by encouraging consumers to repurchase with the same retailer. However, consumers do not rely exclusively on their own purchasing experience to make such decision while the extant literature has evidenced the influencing role of word of mouth (WOM). As such, the relationships between satisfaction, trust and repurchase intention are subject to change due to the impact of WOM communicated among consumers.

Although academics have paid much attention in studying these critical concepts, a comprehensive understanding about the associations among satisfaction, trust, repurchase intention and WOM is seemingly neglected. Specifically, the studies working on these concepts are separated that cannot help to integrate findings. For instant, in a study investigating the role of consumers' satisfaction in online travel services, Ha, Janda and Muthaly (2010) has proved the direct and indirect influence of satisfaction on repurchase intention. Besides, satisfaction is a significant predictor of consumer trust and loyalty that, in turn, result in repurchase intention (Chinomona \& Sandada, 2013). Similarly, the moderating effect of word of mouth on the association between consumer trust and purchase intention has been examined and validated in the context of tourism (Lin \& Lu, 2010). In addition, the 
studies are solely conducted in either online or offline context that leads to the difficulty in comparing and contrasting the differences between these two primary shopping environments.

In the context of Vietnam, while online shopping has remarkably proliferated recently, WOM becomes increasingly important since it is the key information source for online shoppers. This leads to an unanswered question that whether WOM impacts on consumers differently due to different shopping contexts. Given that online shopping has significantly emerged, most of consumers still prefer to offline store or market for their purchasing. Although the literature on satisfaction, trust, repurchase intention and WOM has been relatively intensive, few empirical research has been conducted in Vietnam that exclusively focus on identifying the antecedents predicting them (Đinh Phi Hổ, 2009; Nguyễn Thành Phương; 2014). As a result, the associations between these concepts remain unclear in both offline and online shopping. Thus, studying the relationships between these critical factors help to provide comprehensive knowledge about the attitude and consuming behavior of Vietnamese consumers in both shopping environments.

Thus, this study contributes to the literature by: (1) validating the moderating effect of WOM on the relationship between satisfaction and trust; (2) clarifying the differences in this moderating role of WOM between online and offline shopping; (3) identifying the significant dimensions of trust concept that positively influence on repurchase intention in each shopping environment; and (4) introducing a new approach to investigate the associations between satisfaction, trust and WOM thoroughly by utilizing Cognitive Dissonance Theory (CDT). These findings serve as the foundational understanding that helps practitioners to improve their business performance by satisfying consumers that results in higher level of consumer trust and repurchase intention. In addition, the significance of well-managed WOM is also validated.

\section{Theoretical background and research framework}

Satisfaction concept has been widely studied in the literature and has been defined in many different perspectives. Anderson and Srinivasan (2003) define satisfaction as the extent to which consumers are satisfied with the previous shopping experience. It refers to consumers' post purchase evaluation resulted by considering the level of consumers' expectations that are met by consuming product or service (Johnson \& Fornell, 1991). In both offline and online shopping contexts, satisfaction not only facilitates consumers to make purchase with the retailers (Bhattacherjee, 2001) but also significantly forms and tightens buyer - seller relationship (Evanschitzky et al., 2004). In this study, the concept of satisfaction proposed by Johnson and Fornell (1991) is adopted. Specifically, satisfaction is defined as the overall evaluation by comparing the prior expectations and the perceived performance of the purchased product or service.

The importance of trust is widely recognized since academics from several research fields have contributed to the wide literature of this concept (Connolly \& Bannister, 2008). For instant, trust refers to the willingness to rely on another party in social transactions that make an individual possibly to be vulnerable (Larges et al., 2008). Trust is built mainly based on individual perception about the others' attributes and behaviors (McKnight et al., 2002). In this study, trust definition is adapted from Mayer et al. (1995) that is conceptualized as the willingness of people to be vulnerable to the actions of others based on the expectation that 
the latter will perform a particular action important to the former, irrespective of the ability to monitor and control the latter. This is the most accurate and comprehensive definition of trust (Bhattercherjee, 2002) that is well suited to both offline and online shopping (McKnight et al., 2002). In addition, Mayer et al. (1995) identify three cognitive components of trust concept including integrity, benevolence and ability.

- Integrity refers to the consumers' belief regarding commitment or obligation fulfillment of the retailers in whole purchasing process.

- Benevolence is the extent to which the retailers are believed to behave appropriately to the consumers even when they can gain benefits by opportunistic behavior.

- Ability refers to the understandings and capability of retailers that are necessary to perform purchasing transactions successfully.

Repurchase intention is the consumers' intention to repurchase products or services from the same retailer that they have made purchasing transactions with (Zeithaml et al., 1996). In another view, Zwass (1998) argues that repurchase intention is consumers' willingness to purchase products or services with the transacted retailers. Thus, in this study, repurchase intention definition is adopted from Zeithaml et al. (1996) that refers to consumers' willingness to repurchase with the retailers they have already had purchasing relationship previously.

$W O M$ is the information communicated among consumers that is about the product, service or retailer (Hu \& cộng sự, 2008). Consumer behavior literature has indicated that WOM influences significantly on consumers' perception that, in turn, impacts their purchase decisions (Sheng, 2012). In the case that consumers receive positive evaluations shared by other buyers, they are more likely to choose the mentioned product or retailer and vice versa. This study approach
WOM only from positive aspect that is considered as satisfied evaluations about the product, service or retailer consumers receive from the others.

The CDT (Festinger, 1957) discusses on the discrepancies in individual's cognitions that influence on the behaviors. The author argues that individual' cognitions are based on several cognitive elements such as his/her own knowledge, attitudes, experience or others' opinions. If an element is logical to another, they are considered as consonant with each other. In contrast, the inconsistency between them results in dissonance that requires a person to change his/her attitude, opinion or behavior to lessen the dissonance (Brehm \& Cohen, 1962). In this study, CDT serves as underlying logic of the moderating effect of WOM on the association between satisfaction and trust in both offline and online shopping contexts.

Kuan et al. (2007) suggest that the reevaluation of trust should be investigated by analyzing both consumers' own purchasing experience and post-purchase information source in an integrated research framework. Specifically, these authors utilize the CDT to propose a conceptual model in which purchasing experience and WOM play moderating role in influencing on the relationship between satisfaction and trust in multichannel shopping. However, Kuan et al. (2007) just provide the propositions for such relationships that are lack of empirical evidences to be supported. In addition, Chinomona and Sandada (2013) has concluded that satisfaction plays a critical role in building consumers' trust and loyalty. Once loyalty is successfully created, consumers are more likely to repurchase with the retailer they have already trusted. In another approach, consumers' satisfaction is one of the primary factors that help to form habit that, in turn, moderates the relationship between online trust and repurchase intention 
(Chiu et al., 2012). Besides, satisfaction also has indirect influence on repurchase intention via mediating role of trust. Furthermore, some authors have interested in examining the moderating role of other factors in affecting satisfaction - trust relationship. For instant, the study of Echanisms et al. (2014) has indicated that consumer protection mechanism moderates both satisfaction - trust relationship and trust - repurchase intention association. Consequently, based on the extent literature, especially the study of Kuan et al. (2007), the research framework of this study is proposed to investigate the relationships among satisfaction, trust, repurchase intention and WOM in an integrated model.

While the extent literature has showed that satisfaction is critical factor predicting consumers' trust (Yoon, 2002), it is built by their own purchasing experience (Garbarino \& Johnson, 1999). This argument is underlined by Chinomona and Sandada (2013). Besides, the influence of satisfaction on repurchase intention is mediated by several factors including adjusted expectation, positive attitude and trust. Because of these, we propose that after consuming the product, the satisfaction of consumers is created if their expectations are successfully met. This positive experience, then, helps to build their trusting belief regarding the retailer. This trust building process is echoed by some previous studies (Dabholkar \& Sheng, 2012). Thus, it is expected that a higher level of satisfaction consumers have results in a higher level of trust they possess regarding the retailer. Therefore, the relationship between satisfaction and trust is proposed as follows:

H1: Satisfaction is positively associated to trust including all three components: (a) integrity; (b) benevolence; and (c) ability.

Repurchase intention is one of the most critical consequences of trust. Hennig-Thurau and Klee (1997) argue that repurchase intention is best explained by consumers' trust.
Besides, Grewal et al. (2004) indicate that even when consumers are satisfied with the retailer, repurchase decision are not likely to be made if there is a lack of trust in consumers' perception. This is consistent with the findings of $\mathrm{Ha}$ et al. (2010) who evidence that trust plays a significant role in driving consumers' behavioral intention. In addition, much research on consumers' trust concept (McKnight et al., 1998; Bhattacherjee, 2002) has proven the direct impact of trust on purchase intention. Therefore, it is expected that consumers who have high level of trust regarding the retailer are more likely to make repurchase transaction with the trusted seller. Thus, the relationship between trust and repurchase intention is hypothesized as follow:

H2: Trust represented by three components including: (a) integrity; (b) benevolence; and (c) ability is positively associated with repurchase intention.

According to CDT, when a person faces cognitive dissonance, (s)he tends to reduce this unexpected situation by adjusting his/her attitude, perception or behavior (Oshikawa, 1969). Thus, it can be inferred that consumers will reevaluate their post-purchase perception regarding the retailer based on the nature of received WOM (Santos \& Boote, 2003). Specifically, after purchasing with the retailer, consumers' judgment is founded on not only their own purchasing experience with the provider but WOM they receive from other buyers as well. These reevaluations serve as the basis for consumers' next purchasing decision. Thus, it is expected that the received WOM can moderate the relationship between satisfaction and consumers' trust regarding the retailer. Consequently, the moderating role of WOM is hypothesized as follows:

H3: The association between satisfaction and trust is affected by WOM.

Underlying by the proposed hypotheses, the research framework of this study is illustrated as follows (Figure 1): 


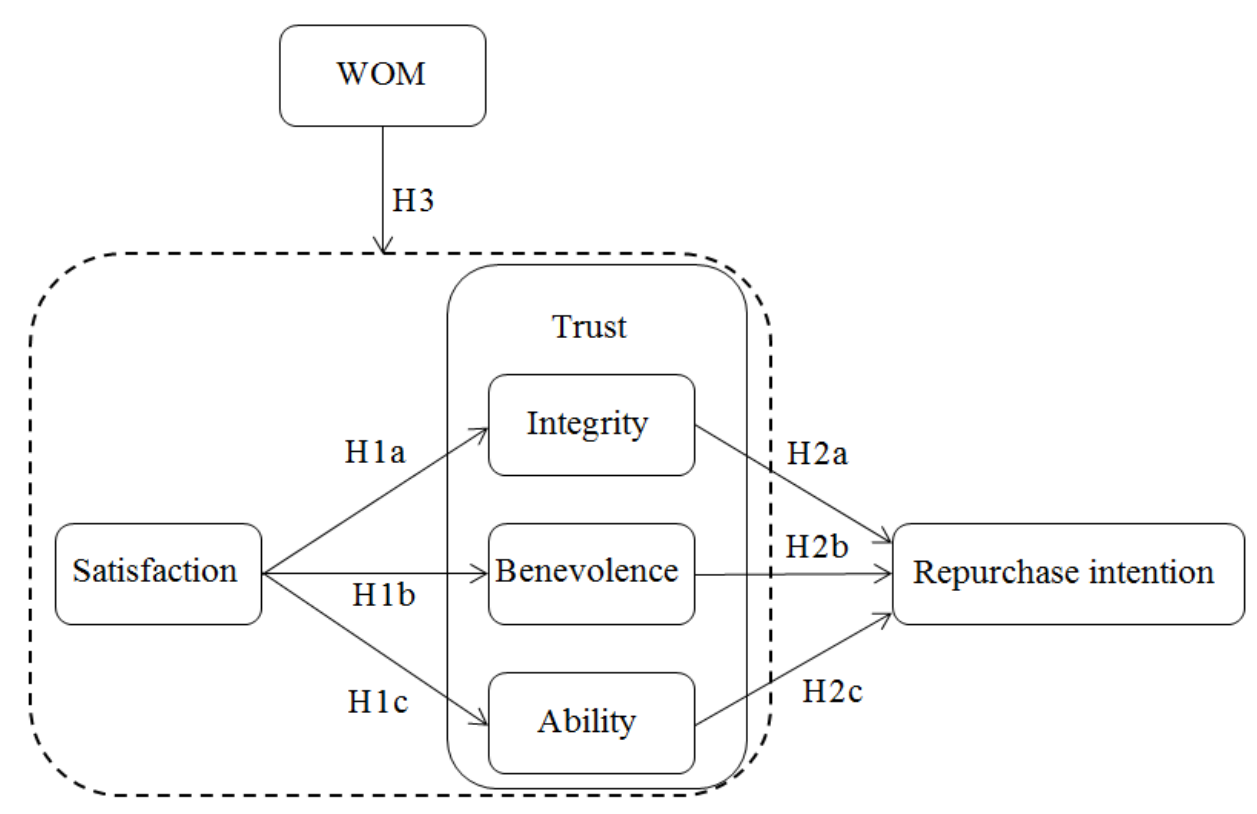

Figure 1. Proposed research framework

\section{Research methodology}

Mix-method methodology that combines both qualitative and quantitative technique is utilized for investigating the associations between research concepts in this study. In the qualitative stage, seven participants who are offline and online consumers join in group discussion. The objective of this qualitative step is to refine the research framework and ensure the appropriateness of the measurement instrument.

The results of this qualitative stage help to produce the official measurement instruments (Table 1) that are utilized to collect quantitative survey data. The sample measurement items used to collect quantitative data are described in Appendix 1. By adopting convenient sampling method, the participants who are offline and online consumers are considered as appropriate respondents of this study. In general, the quantitative data is collected from 296 online consumers and 169 offline buyers. The data is collected in Ho Chi Minh City that is then analyzed by employing structural equation modeling (SEM) supported by AMOS with maximum likelihood estimation in order to test the proposed hypotheses.

\section{Table 1}

Measurement scales for the research concepts

\begin{tabular}{|c|c|c|c|}
\hline \multicolumn{2}{|c|}{ Factors/dimensions } & Source of Scales & Observed variables \\
\hline \multicolumn{2}{|c|}{ Satisfaction (ST) } & (Khalifa \& Liu, 2007) & 4 \\
\hline \multicolumn{2}{|c|}{ WOM (WO) } & (Goyette, Ricard, Bergeron, \& Marticotte, 2010) & 6 \\
\hline \multirow{3}{*}{ Trust } & Integrity (IN) & \multirow{3}{*}{ (Ho \& Chen, 2014) } & 5 \\
\hline & Benevolence (BE) & & 5 \\
\hline & Ability (AB) & & 7 \\
\hline \multicolumn{2}{|c|}{ Repurchase intention (RP) } & (Khalifa \& Liu, 2007) & 5 \\
\hline
\end{tabular}


The demographics of both online and offline consumers are illustrated in Table 2. In general, while online consumers are younger, their level of education is higher than offline consumers.
Besides, most of online consumers make purchase once or twice a month in comparison to over four times per month for purchasing frequency of dominant portion offline consumers.

\section{Table 2}

Respondents' characteristics

\begin{tabular}{|c|c|c|c|c|c|}
\hline \multirow{2}{*}{\multicolumn{2}{|c|}{ Attributes }} & \multicolumn{2}{|c|}{ Online shopping } & \multicolumn{2}{|c|}{ Offline shopping } \\
\hline & & N.o & $\%$ & N.o & $\%$ \\
\hline \multirow{2}{*}{ Gender } & Male & 117 & 39.5 & 63 & 37.3 \\
\hline & Female & 179 & 60.5 & 106 & 62.7 \\
\hline \multirow{3}{*}{ Age } & $\leq 25$ & 133 & 44.9 & 16 & 9.5 \\
\hline & From 26 to 29 & 115 & 38.9 & 62 & 36.7 \\
\hline & $\geq 30$ & 48 & 16.2 & 91 & 53.8 \\
\hline \multirow{3}{*}{$\begin{array}{l}\text { Purchasing frequency } \\
\text { (per month) }\end{array}$} & Once or twice & 235 & 79.4 & 21 & 12.4 \\
\hline & Three or four times & 42 & 14.2 & 63 & 37.3 \\
\hline & More than four times & 19 & 6.4 & 85 & 50.3 \\
\hline \multirow{4}{*}{$\begin{array}{l}\text { Educational } \\
\text { background }\end{array}$} & High school & 4 & 1.4 & 23 & 13.6 \\
\hline & Associate Bachelor & 31 & 10.5 & 85 & 50.3 \\
\hline & Bachelor & 258 & 87.2 & 59 & 34.9 \\
\hline & Graduate & 3 & 1.0 & 2 & 1.2 \\
\hline
\end{tabular}

Source: Data analysis's result

\section{Research results}

A reliability analysis of multi-item scales had favorable results. Although Cronbach's alpha analysis for both offline and online group figured out that two items measuring benevolence and repurchase intention possessed factor loading coefficient lower than 0.3, all Cronbach's coefficient $\alpha$ values exceeded 0.6 (Nunnally \& Bernstein, 1994) after removing these two items from the analysis. All remaining 30 observed variables contributed significantly to the Cronbach's alpha of the factors that are adopted to perform exploratory factor analysis (EFA). This measures refining process for both online and offline consumers utilizing Promax rotation and Principle Axis factoring showed that there are 6 extracted factors explained by 27 appropriate items with satisfactory figures including $\mathrm{KMO}(>0.5)$, significant Barlet sphericity test $(\mathrm{p}<0.05)$, total variance extracted $(>50 \%)$ (Nunnally \& Bernstein, 1994), and Eigenvalue ( $>1$ ) (Nguyễn Đình Thọ, 2011). Specifically, while the KMO sampling-adequacy measure reached 0.896 and 0.864 for online and offline data respectively, Bartlett sphericity tests were significant for both data group. In addition, 27 items with eigenvalues accounting for $69.75 \%$ (online) and $68.3 \%$ (offline) of the total variance were retained for next analyzing step.

On the other hand, the validity was assessed by utilizing confirmatory factor analysis. The final analysis process that was deployed after removing two items measuring ability and benevolence due to low standardized factor loading indicated that the measurement model provided a good fit to the data of online $\left(\chi^{2}=366.526\right.$, df $=260, \mathrm{p}=$ 
$0.000)$ and offline $\left(\chi^{2}=370.378, \mathrm{df}=260, \mathrm{p}=\right.$ 0.000). Besides, all critical indices satisfied recommended value (Carmines \& McIver, 1981) including CMIN/df (<2); GFI, CFI, TLF $(>0.9)$; and RMSEA $(<0.05)$. In addition, the measurement instruments of these 6 factors explained by 25 observed variables had sufficient composite reliability, convergent validity and discriminant validity. The results were specifically described in Table 3.

\section{Table 3}

Factor loading and reliability of the measurement intruments

\begin{tabular}{|c|c|c|c|c|c|c|}
\hline \multirow{2}{*}{ Factor/dimension } & \multicolumn{2}{|c|}{ Standardized coefficient } & \multicolumn{2}{|c|}{$\begin{array}{c}\text { Composite reliability } \\
(C R)\end{array}$} & \multicolumn{2}{|c|}{ Total variance extracted } \\
\hline & Online & Offline & Online & Offline & Online & Offline \\
\hline \multicolumn{3}{|l|}{ Ability } & 0.887 & 0.881 & $56.88 \%$ & $55.63 \%$ \\
\hline $\mathrm{AB} 1$ & 0.672 & 0.627 & & & & \\
\hline $\mathrm{AB} 2$ & 0.71 & 0.695 & & & & \\
\hline $\mathrm{AB} 3$ & 0.694 & 0.674 & & & & \\
\hline $\mathrm{AB} 4$ & 0.719 & 0.717 & & & & \\
\hline AB5 & 0.848 & 0.868 & & & & \\
\hline $\mathrm{ABn}$ & 0.86 & 0.86 & & & & \\
\hline \multicolumn{3}{|l|}{ Integrity } & 0.965 & 0.960 & $\mathbf{8 7 . 3 3 \%}$ & $85.86 \%$ \\
\hline IN1 & 0.943 & 0.915 & & & & \\
\hline IN2 & 0.933 & 0.922 & & & & \\
\hline IN3 & 0.927 & 0.951 & & & & \\
\hline IN4 & 0.935 & 0.918 & & & & \\
\hline \multicolumn{3}{|l|}{ Benevolence } & 0.936 & 0.932 & $78.43 \%$ & $\mathbf{7 7 . 4 4 \%}$ \\
\hline BE1 & 0.869 & 0.837 & & & & \\
\hline BE3 & 0.873 & 0.857 & & & & \\
\hline BE4 & 0.869 & 0.888 & & & & \\
\hline BEn & 0.93 & 0.935 & & & & \\
\hline \multicolumn{3}{|l|}{ WOM } & 0.918 & 0.907 & $73.62 \%$ & $70.97 \%$ \\
\hline WO1 & 0.785 & 0.724 & & & & \\
\hline WO2 & 0.875 & 0.881 & & & & \\
\hline WO4 & 0.892 & 0.883 & & & & \\
\hline WO5 & 0.876 & 0.871 & & & & \\
\hline \multicolumn{3}{|c|}{ Repurchase intention } & 0.908 & 0.889 & $71.31 \%$ & $66.80 \%$ \\
\hline RP1 & 0.766 & 0.757 & & & & \\
\hline $\mathrm{RP} 2$ & 0.86 & 0.788 & & & & \\
\hline RP3 & 0.831 & 0.79 & & & & \\
\hline RP4 & 0.914 & 0.924 & & & & \\
\hline \multicolumn{3}{|l|}{ Satisfaction } & 0.912 & 0.901 & $77.50 \%$ & $75.35 \%$ \\
\hline ST1 & 0.833 & 0.807 & & & & \\
\hline ST2 & 0.894 & 0.898 & & & & \\
\hline ST3 & 0.912 & 0.896 & & & & \\
\hline
\end{tabular}

Source: Data analysis's results 
After assessing measurement model to validate that the measurement scales were undimensional and reliable, the structural equation modeling (SEM) techniques via the AMOS program is utilized to determine the efficacy of the model and the proposed hypotheses. The structural model was analyzed with maximum likelihood method (ML) that provided significant results for both online and offline data. These satisfactory results are illustrated in Table 4, Figure 2 and Figure 3 that have proved that there was a reasonable overall fit between the models and the observed data.

\section{Table 4}

Fit indices of the model for both data groups

\begin{tabular}{|l|c|c|c|l|c|c|c|l|}
\hline Shopping context & $\chi^{2}$ & $\boldsymbol{d} \boldsymbol{f}$ & $\boldsymbol{p}$ & $\boldsymbol{C M I N} / \boldsymbol{d f}$ & $\boldsymbol{C F I}$ & $\boldsymbol{T L I}$ & $\boldsymbol{G F I}$ & $\boldsymbol{R M S E A}$ \\
\hline Online & 322.2 & 180 & 0.000 & 1,790 & 0,972 & 0,967 & 0,907 & 0.0525 \\
\hline Offline & 351.225 & 183 & 0.000 & 1,919 & 0,938 & 0,929 & 0,845 & 0.074 \\
\hline
\end{tabular}

Furthermore, in the bootstrapping test, the 95 percent bias-corrected bootstrap confidence intervals were obtained from 500 bootstrap samples for both online and offline context. The results indicated that all standard error bias (SE-Bias) between bootstrapping estimates and ML estimates were not significant ( $\mathrm{p}$ value $<0.05$ ). In addition, all critical ratio indexes were satisfied $(<2.5)$. Thus, all the estimates in the structural equation model for both online and offline data were considered reliable. Consequently, it was indicated that the models were reasonably fit to the observed data in both online and offline shopping contexts.

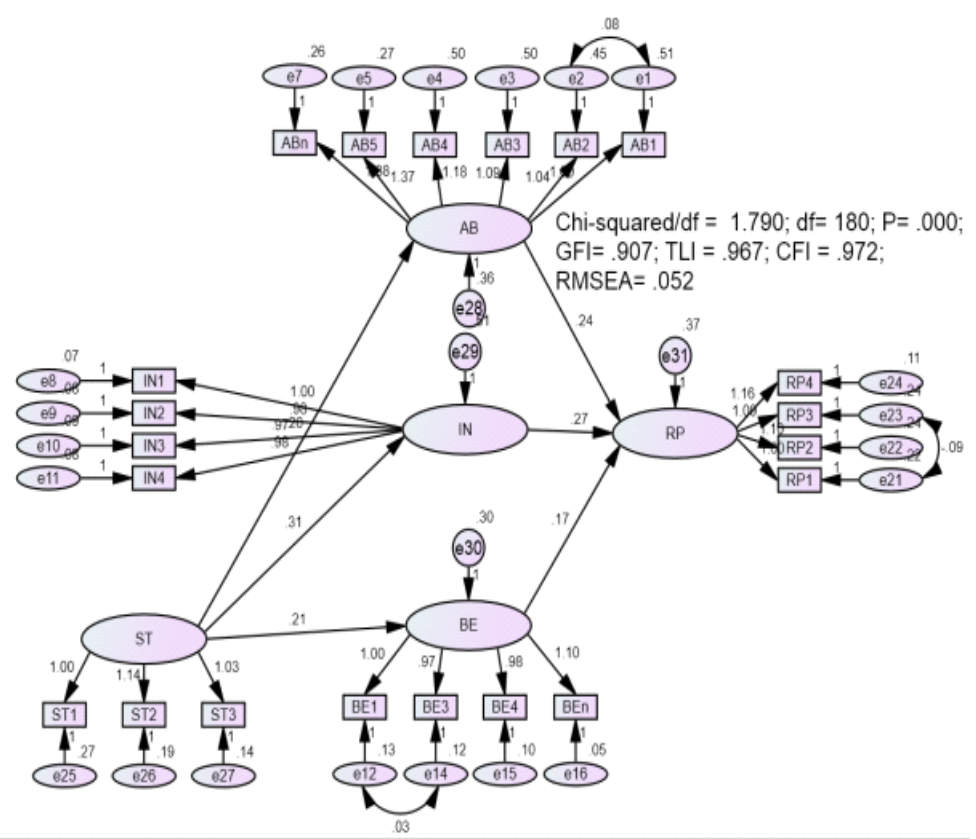

Figure 2. Results of structural equation model analysis (online) 


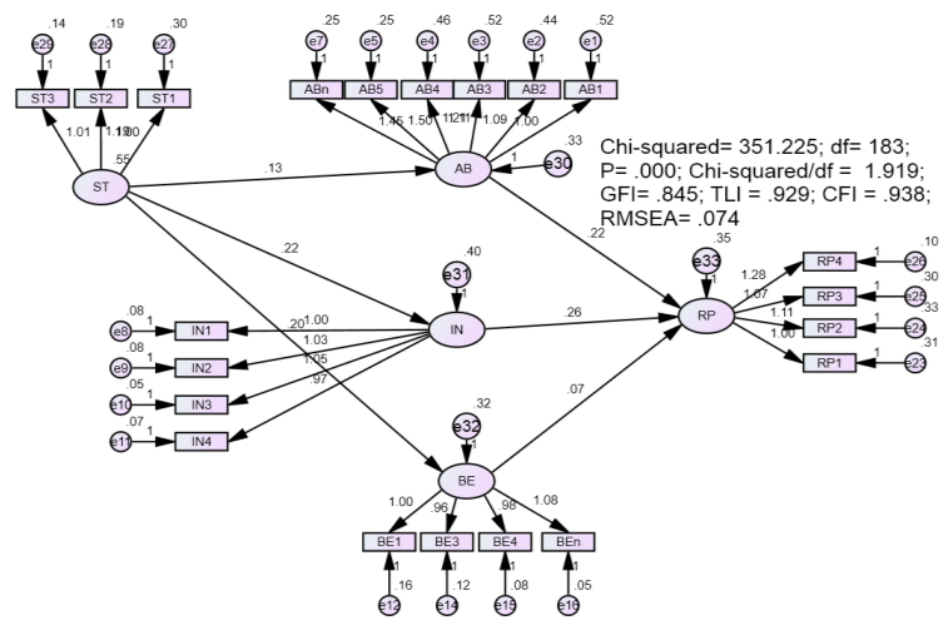

Figure 3. Results of structural equation model analysis (offline)

As reported in Table 5, the analytical results indicated that satisfaction is positively related to all three dimensions of trust in online shopping context, thus H1a, H1b and H1c are supported. In offline shopping, the positive influences of satisfaction on two of three dimensions of trust are confirmed that support $\mathrm{H} 1 \mathrm{a}$ and H1b while H1c was not supported.
These results showed a slight difference in the satisfaction - trust relationship in online and offline shopping context. Specifically, while consumers' satisfaction was positively associated with all three dimensions of trust in online shopping, its impact was only significant on integrity and benevolence component of trust in offline shopping.

\section{Table 5}

H1 hypothesis testing results for both online and offline shopping context

\begin{tabular}{|c|l|c|c|c|c|c|}
\hline Hypothesis & \multicolumn{1}{|c|}{ Relationship } & $\begin{array}{c}\text { Standardized } \\
\boldsymbol{\beta}\end{array}$ & S.E. & C.R. & P & Testing result \\
\hline Online & \multicolumn{7}{|l|}{} \\
\hline H1a & Satisfaction - Integrity & 0.318 & 0.058 & 5.253 & $* * *$ & Supported \\
\hline H1b & Satisfaction - Benevolence & 0.289 & 0.046 & 4.65 & $* * *$ & Supported \\
\hline H1c & Satisfaction - Ability & 0.254 & 0.052 & 3.884 & $* * *$ & Supported \\
\hline Offline & Satisfaction - Integrity & 0.250 & 0.072 & 3.054 & 0.002 & Supported \\
\hline H1a & Satisfaction - Benevolence & 0.252 & 0.066 & 3.027 & 0.002 & Supported \\
\hline H1b & Satisfaction - Ability & 0.161 & 0.067 & 1.87 & 0.062 & Not supported \\
\hline H1c &
\end{tabular}

Source: Data analysis results

The hypothesis testing results for the relationship between trust and repurchase intention in online and offline shopping are illustrated in Table 6 below. It was showed that there was also a difference of the influence of trust on repurchase intention between online and offline shopping. For instant, while all three trust components significantly affect the repurchase intention of online consumers, benevolence dimension of trust had no impact on the repurchase intention of offline consumers. Thus, in online context, all $\mathrm{H} 2$ hypotheses were supported whereas only $\mathrm{H} 2 \mathrm{a}$ and $\mathrm{H} 2 \mathrm{c}$ were significantly evidenced in offline shopping. 


\section{Table 6}

$\mathrm{H} 2$ hypothesis testing results for both online and offline shopping context

\begin{tabular}{|c|l|c|c|c|c|c|c|}
\hline Hypothesis & Relationship & Standardized $\beta$ & S.E. & C.R. & P & $\begin{array}{c}\text { Testing } \\
\text { result }\end{array}$ \\
\hline Online & \multicolumn{7}{|c|}{} \\
\hline H2a & Integrity - Repurchase intention & 0.304 & 0.052 & 5.236 & $* * *$ & Supported \\
\hline H2b & Benevolence - Repurchase intention & 0.143 & 0.067 & 2.476 & 0.013 & Supported \\
\hline H2c & Ability - Repurchase intention & 0.225 & 0.066 & 3.683 & $* * *$ & Supported \\
\hline Mua tại của hàng & \multicolumn{7}{|c|}{} \\
\hline H2a & Integrity - Repurchase intention & 0.266 & 0.078 & 3.307 & $* * *$ & Supported \\
\hline H2b & Benevolence - Repurchase intention & 0.061 & 0.085 & 0.771 & 0.441 & $\begin{array}{c}\text { Not } \\
\text { supported }\end{array}$ \\
\hline H2c & Ability - Repurchase intention & 0.205 & 0.091 & 2.447 & 0.014 & Supported \\
\hline
\end{tabular}

Source: Data analysis results

In order to test the moderating effects of WOM on the relationship between satisfaction and trust, a multi-group structural equation model was constructed. A multi-group analysis is a hierarchical approach in which two sub-groups are compared (Noh \& Lee, 2016). The data of both online and offline shopping was divided into 2 sub-groups: high positive WOM received and low positive WOM received based on the median of WOM scores. For each shopping type, a comparison was made between these two groups. This was to examine whether there was a difference between these two groups through Chisquared difference test. These results helped to validate the moderating effect of WOM on the relationship between satisfaction and trust in both online and offline shopping. Table 7 presents the results of the test.

\section{Table 7}

Multi-group analysis results

\begin{tabular}{|c|c|c|c|}
\hline Model & Chi-squared & $d f$ & Pvalue \\
\hline \multicolumn{4}{|l|}{ Online } \\
\hline Constrained model & 662,316 & 366 & \\
\hline Unconstrained model & 488,5 & 360 & \\
\hline Difference & 173,816 & 6 & $6,97298 E-35$ \\
\hline \multicolumn{4}{|l|}{ Offline } \\
\hline Constrained model & 687.36 & 372 & \\
\hline Unconstrained model & 587.352 & 366 & \\
\hline Difference & 100.008 & 6 & $2.4997 E-19$ \\
\hline
\end{tabular}

Source: Data analysis results 
The result indicates that the difference between constrained model and unconstrained model for both online and offline shopping was significant $(\mathrm{p}<0.05)$. In other words, the influences of satisfaction on trust vary due to the WOM consumers received from other buyers. This confirms the moderating effect of WOM on the relationship between satisfaction and trust in both online and offline shopping. Thus, $\mathrm{H} 3$ was supported. The standardized estimates resulted from analyzing structural equation model for both low and high positive WOM groups are specifically presented in Table 8 . These figures clearly mirror the differences in satisfaction trust relationships under moderating role of WOM for each shopping context.

\section{Table 8}

Multi-group analysis results

\begin{tabular}{|l|l|c|c|}
\hline \multirow{2}{*}{$\begin{array}{c}\text { Shopping } \\
\text { context }\end{array}$} & \multicolumn{1}{|c|}{ Relationship } & \multicolumn{2}{c|}{ Standardized $\beta$} \\
\cline { 3 - 4 } & & High positive WOM & Low positive WOM \\
\hline \multirow{3}{*}{ Online } & Satisfaction - Integrity & 0.248 & 0.465 \\
\cline { 2 - 4 } & Satisfaction - Benevolence & 0.323 & 0.530 \\
\cline { 2 - 4 } & Satisfaction - Ability & 0.247 & 0.509 \\
\hline \multirow{2}{*}{ Offline } & Satisfaction - Integrity & 0.020 & 0.322 \\
\cline { 2 - 4 } & Satisfaction - Benevolence & 0.053 & 0.263 \\
\hline
\end{tabular}

Source: Data analysis results

\section{Discussion and implication}

This study provides a good fit of the model to the data in both online and offline shopping and the empirical results help to validate the moderating effects of WOM on the relationship between satisfaction and trust for both shopping contexts. In addition, the research also indicates the effect of satisfaction on trust that, in turn, results in repurchase intention.

First, WOM does have moderating effect on the relationship between satisfaction and trust for not only online consumers but also for offline buyers. Specifically, in both shopping environments, when consumers receive fewer positive WOM from others, their satisfaction has greater influence on their trust in comparison to the situation much positive WOM received. To figure out the reasons explaining this finding, the authors invite participants to join in group discussion. The results of this extra qualitative stage help to identify two main causes reasoning for this interesting research result.

On one hand, the consumers who have received little positive WOM evaluating the product or retailer transacted form their trusting belief mainly based on their own purchasing experience rather relying on WOM received. In contrast, when consumers collect much positive WOM from other buyers, the impact of their own experience in purchasing with the retailers has been reduced due to the contribution of other factors. On the other hand, the participants have showed that they face uncertainties in the case that there are too many comments or reviews positively evaluating the retailers. These perceptions result in the reduction of their trust in comparison to the situation when they receive appropriate amount of positive WOM. This logic has been echoed in the research working on information overload issue in shopping contexts (Furner, Zinko, \& Zhu, 2016). 
Thus, it can be inferred that receiving positive WOM plays a vital role in building consumers' trusting belief regarding the retailers in both online and offline shopping environment. However, the appropriate amount of positive comments or reviews share by consumers has better effects in trust building role of existing satisfaction. Therefore, the retailers are suggested to encourage their consumers to leave product comments or reviews by several ways. For instance, they should record purchasing information of each customer that helps to classify the clients into many groups. This makes retailers' promotion campaign more efficient to gain more profits from their business. Besides, consumers are more likely to share their satisfied shopping experience or even introduce their friends or relatives to make the purchase with the retailers when they receive discount or other added values from the sellers. In addition, creating online fan-pages or offline brand community is probably an efficient way to gain more benefits from the WOM shared by consumers. However, it is worth noticing that the retailers have to well manage the information shared among their consumers since too much positive WOM result in more uncertainties consumers perceive and lower influence of satisfaction on consumers' trust. Thus, the retailers need to identify a suitable mechanism to maintain an appropriate amount of positive WOM shared among their consumers.

Second, the study indicates that once online retailers meet consumers' demand that results in consumers' satisfaction, consumers' trust will be built in all three dimensions including commitment fulfillment, consumers' benefit orientation and necessary capability. For offline consumers, their satisfaction helps to create the trusting belief in two dimensions including commitment fulfillment and consumers' benefit orientation. In this shopping context, consumers' satisfaction does not make retailers' capability reliable in the consumers' perception. This can be explained by the existence of physical interactions between the buyers and retailers. Because of this, offline consumers are able to evaluate the ability of the retailer directly instead of relying on other cues, i.e. via satisfaction perception. In general, this finding acknowledges the significance of creating satisfaction to consumers regardless of shopping context. Based on such result, it is implied that consumers' need identifying and, consequently, satisfying are critical to build consumers' satisfaction.

Third, trust is significantly evidenced to be the encouraging factor that drives consumers to make repurchase decision with the same retailer. Specifically, retailers' commitment fulfillment plays critical role in both two shopping environments. Similarly, necessary capability has also the same role since it positively results in increasing repurchase intention for online as well as offline consumers. In addition, in offline shopping context, since the consumers are able to physically experience the real product or directly interact with the sellers to justify the demanded product or service, they can definitely decide which is the best solution meeting their purchasing expectation. Thus, the most suitable product or buying solution is probably certain to the offline consumers that reasons why their repurchase intention is not affected by retailers' benevolence perception. This is different from online shopping since the positive relationship between benevolence dimension of trust and repurchase intention of online consumers has been significantly proven. In general, it is suggested that both online and offline retailers need to build and maintain their consumers' trust in all three primary ways including fulfilling the committed policies, orientating on consumers' benefits and improving their necessary 
retailing competence.

\section{Limitations and future research}

Although the results of this study provide a comprehensive understanding of moderating effect of WOM and the associations between many critical concepts in shopping for both online and offline channels, there are still some limitations that needed to be addressed by supplementary research. First, the sample size for offline participants is relatively low (169 respondents) that seems to be not proportional to the sample size of online consumers. Thus, future research should increase the sample size of offline respondents to better compare the associations proposed in the research framework. Second, future studies should extend the data by collecting in other cities or provinces. By doing this, the generalizability of the research becomes better. Third, while this study only considers trust-building role of satisfaction, the future research is suggested to add some other trust's antecedents to proposed more comprehensive research framework

\section{References}

Anderson R.E., \& Srinivasan S.S. (2003). E-satisfaction and E-loyalty: a contingency framework. Psychology and Marketing, 20(2), 123-138.

Bhattacherjee, A. (2001). An empirical analysis of the antecedents of electronic commerce service continuance. Decision Support System, 32(2), 201-214.

Bhattacherjee, A. (2002). Individual trust in online firms: scale development and initial test. Journal of Management Information Systems, 19(1), 211-242.

Brehm, J.W., \& Cohen, A.R. (1962), Explorations in Cognitive Dissonance. New York: John Wiley and Sons, Inc., 306-308.

Carmines, E.G., \& McIver, J.P. (1981). Analyzing models with unobserved variables: Analysis of covariance structures. Social measurement: Current issues, 65-115.

Chinomona, R., \& Sandada, M. (2013). Customer Satisfaction, Trust and Loyalty as Predictors of Customer Intention to Re-Purchase South African Retailing Industry. Mediterranean Journal of Social Sciences, 4(14), 437.

Chiu, C.M., Huang, H.Y., \& Yen, C.H. (2012). Antecedents of trust in online auctions. Electronic Commerce Research and Applications, 9(2), 148-159.

Dabholkar, P.A., \& Sheng, X. (2012). Consumer participation in using online recommendation agents: effects on satisfaction, trust, and purchase intentions. The Service Industries Journal, 32(9), 1433-49.

Đinh Phi Hổ, (2009). Mô hình định lượng đánh giá sự hài lòng của khách hàng ứng dụng cho hệ thống ngân hàng thương mại. Tạp chí Quản lý kinh tế, 07-12.

Echanisms, M., Mccole, P., Ramsey, E., \& Lim, K.H. (2014). Trust, satisfaction, and online repurchase intention: The moderating role of perceived effectiveness of e-commerce institutional. MIS Quarterly, 38(2), 407-427.

Evanschitzky, H., Iyer, G.R., Hesse, J., \& Ahlert, D. (2004). E-satisfaction: a re-examination. Journal of Retailing, 80(3), 239-247.

Festinger, L. (1957). A Theory of Cognitive Dissonance. Row, Peterson, Evanston, IL.

Furner, C.P., Zinko, R., \& Zhu, Z. (2016). Electronic word-of-mouth and information overload in an experiential service industry. Journal of Service Theory and Practice, 26(6).

Garbarino, E., \& Johnson, M.S. (1999). The Different Roles of Satisfaction, Trust and Commitment in Customer Relationships. Journal of Marketing, 63, 70-87.

Goyette, I., Ricard, L., Bergeron, J., \& Marticotte, F. (2010). E-WOM scale: Word-of-mouth measurement scale for e-services context. Canadian Journal of Administrative Sciences, 27(1), 5-23. 
Grewal, D., Hardesty, D.M. \& Iyer, G.R. (2004). The effects of buyer identification and purchase timing on consumers' perceptions of trust, price fairness, and repurchase intentions. Journal of Interactive Marketing, $18(4), 87-100$.

Ha, H., Janda, S., \& Muthaly, S. (2010). A new understanding of satisfaction model in e-re-purchase situation. European Journal of Marketing, 44(7/8), 997-1016.

Hennig-Thurau, T., \& Klee, A. (1997). The impact of customer satisfaction and relationship quality on customer retention: a critical reassessment and model development. Psychology \& Marketing, 14(8), 737-64.

Ho, T.H.L. \& Chen, Y. (2014). Vietnamese consumers' intention to use online shopping: the role of trust. International Journal of Business and Management, 9(5), 145.

Hu, N., L. Liu, \& Zhang, J.J., (2008). Do online reviews affect product sales? The role of reviewer characteristics and temporal effects. Inf Technol Manage, 9, 201-214.

Johnson, M.D., \& Fornell, C.A. (1991). Framework for comparing customer satisfaction across individuals and product categories. Journal of Economic Psychology, 12(2), 267-286.

Khalifa, M., \& Liu, V. (2007). Online consumer retention: contingent effects of online shopping habit and online shopping experience. European Journal of Information Systems, 16, 780-792.

Kuan, H.H., Bock, G.W., \& Lee, J. (2007). A Cognitive Dissonance Perspective of Customers' Online Trust in Multi-Channel Retailers. ECIS 2007 Proceedings, 13-23.

Lages, L.F., Lancastrea, A., \& Lages, C. (2008). The B2B-RE- LPERF Scale and Scorecard: Bringing Relationship Marketing Theory into Business-to-Business Practice. Industrial Marketing Management, 37(6), 686-97.

Lin, L.Y., \& Lu, C.Y. (2010). The influence of corporate image, relationship marketing, and trust on purchase intention: the moderating effects of word-of-mouth. Tourism Review, 65(3), 16-34.

Mayer, R.C., Davis, J.H., \& Schoorman, F.D. (1995). An Integrative Model of Organizational Trust. Academy of Management Review, 20(3), 709-734.

McKnight, D.H., Choudhury, V., \& Kacmar, C. (2002). Developing and Validating Trust Measures for eCommerce: An Integrative Typology. Information Systems Research, 13(3), 334-359.

Noh, M.J., \& Lee, K.T. (2016). An analysis of the relationship between quality and user acceptance in smartphone apps. Information Systems and E-Business Management, 14(2), 273-291.

Nunnally, J.C., \& Bernstein, I.H. (1994). Psychometric Theory. New York: McGraw-Hill.

Nguyễn Đình Thọ (2011). Phuoong pháp nghiên cưu khoa học trong kinh doanh - Thiết kế và thực hiện, NXB Lao Động Xã Hội, TP.HCM.

Nguyễn Thành Phương (2014). Các yếu tố ảnh huởng đến lòng tin của khách hàng đối với nhà bán lẻ trục tuyến tại Việt Nam. Luận văn thạc sĩ kinh tế.

Oshikawa, S. (1969). Can Cognitive Dissonance Theory Explain Consumer Behavior?. Journal of Marketing, 33, 44-49.

Santos, J., \& Boote, J. (2003). A Theoretical Exploration and Model of Consumer Expectations, Post- Purchase Affective States and Affective Behavior. Journal of Consumer Behavior, 3(2), 142-156.

Sheng, C.L. (2012). Consumer Decisions: The Effect of Word-of-Mouth. International Journal of Organizational Innovation, 4(3), 188-196.

Yoon, S. (2002). The antecedents and consequences of trust in online-purchase decisions. Journal of Interactive Marketing, 16(2), 47-63.

Zeithaml, V.A., Berry L., \& Parasuraman, A. (1996). The behavioral consequences of service quality. Journal of Marketing, 60(2), 31-46.

Zwass, V. (1998). Structure and macro-level impacts of electronic commerce: from technological infrastructure to electronic marketplace. Kendall, K. (Ed.), Emerging Information Technologies. CA: Sage, Thousand Oaks. 